\title{
HARMONISASI PEMERINTAH PUSAT DENGAN DAERAH SEBAGAI EFEKTIFITAS SISTEM PEMERINTAHAN
}

\author{
Andryan \\ Universitas Muhammadiyah Sumatera Utara \\ Jalan Kapten Mochtar Basri No.3 Medan \\ andryan@umsu.ac.id \\ Naskah diterima: 02/10/2019, direvisi: 13/11/2019, disetujui: 15/11/2019
}

\begin{abstract}
Abstrak
Indonesia sebagai Negara Kesatuan dengan kedaulatan tertinggi dalam pemerintahan berada di tangan Presiden. Salah satu asas Negara Kesatuan yang didesentralisasikan (otonomi), maka ada tugas-tugas tertentu yang diurus oleh Pemerintah Daerah sendiri. Adanya kewenangan yang diurus sendiri oleh Pemerintah Daerah, terdapat berbagai bentuk disharmonisasi antara Kabinet (Pemerintah Pusat) dengan Pemerintah Daerah. Sengketa kewenangan lahan, masalah harmonisasi regulasi, perimbangan keuangan, merupakan bagian dari problematika antara Pusat dengan Daerah. Penataan kembali hubungan pusatdaerah yang lebih harmonis dengan didasarkan pada kemitraan dan saling ketergantungan sistem pemerintahan. Konstruksi hubungan tersebut setidaknya memuat pemikiran ulang mengenai tingkatan pemerintahan, status dan kedudukannya; pembagian wewenang antar berbagai tingkatan pemerintahan; perimbangan keuangan antar tingkatan pemerintahan; partisipasi daerah dalam pembuatan keputusan di tingkat nasional; dan intervensi pusat terhadap daerah. Struktur kabinet pemerintahan mendatang perlu dipastikan mampu mendorong adanya koordinasi dan sinkronisasi yang lebih baik dalam menyelesaikan berbagai persoalan, baik antar-kementerian, lembaga, maupun hubungan pusat dan daerah. Sebagai bagian dalam penguatan sistem presidensial, maka hubungan antara Pemerintah Pusat dan Pemerintah Daerah harus harmonis agar terwujud koordinasi yang baik, sinkronisasi kebijakan, serta kerja sama yang solid. Dengan demikian, pembangunan yang dirancang pemerintah pusat, provinsi, dan kabupaten/kota dapat selaras.
\end{abstract}

Kata Kunci: Harmonisasi, Pemerintah Pusat, Pemerintah Daerah, Sistem Pemerintahan

\begin{abstract}
Indonesia as a unitary state with the highest president. One of the principles of a decentralized Unitary State (autonomy), there are certain tasks that are taken care of by the Regional Government itself. The authority that is administered by the Regional Government itself has various forms of disharmony between the Cabinet (the Central Government) and the Regional Government. Disputes of authority, problems of harmonization of regulations, financial balance, are part of the problems between the Center and the Regions. Rearrangement of more harmonious central-regional relations based on partnerships and interdependence of government systems. The construction of this relationship is issued before its publication, status and position; Division of authority between various levels of government; financial balance between government assemblies; Participation in decision making at the national level; and central intervention on the regions. The future cabinet structure of the government needs to be ensured that supports better coordination and discussion than others, between ministries, institutions, as well as central and regional relations. As part of strengthening the presidential system, the relationship between the Central Government and the Regional Government must be harmonious in order to create good coordination, collaboration, and solid cooperation. Thus, development planned by the central, provincial and district / city governments can be harmonized.
\end{abstract}

Keywords: Harmonization, Central Government, Regional Government, Government System 


\section{A. Pendahuluan}

Undang-Undang Dasar Negara Republik Indonesia Tahun 1945, menyatakan bahwa negara Indonesia adalah Negara Kesatuan yang berbentuk Republik. Sesuai ketentuan Pasal 4 ayat (1) UUD 1945, dalam penyelenggaraan pemerintahan dinyatakan bahwa Presiden Republik Indonesia memegang kekuasaan pemerintahan. Prinsip Negara kesatuan ialah pemegang kekuasaan tertinggi atas seluruh urusan negara adalah pemerintah pusat tanpa ada suatu delegasi atau pelimpahan kewenangan kepada pemerintahan daerah atau urusan pemerintahan tidak dibagi-bagi antara pemerintah pusat dan pemerintah daerah, sehingga urusan-urusan negara dalam negara kesatuan tetap merupakan pemegang kekuasaan tertinggi di negara adalah pemerintah pusat. Meskipun memegang kedaulatan tertinggi dalam pemerintahan, tetapi sistem pemerintahan Indonesia yang menganut asas Negara Kesatuan didesentralisasikan (otonomi), maka ada tugas-tugas tertentu yang diurus oleh pemerintah daerah sendiri.

Dalam sistem pemerintahan dapat juga dipahami sebagai suatu sistem hubungan tata kerja antar lembaga-lembaga negara serta lembagalembaga daerah. Jimly Asshiddiqie membagi sistem pemerintahan menjadi 3 (tiga) kategori, yaitu sistem pemerintahan presidensial (presidential system), sistem pemerintahan parlementer (parliamentary system), dan sistem campuran (mixed system atau hybrid system). ${ }^{1}$ Sistem pemerintahan dalam suatu negara dapat berjalan dengan adanya kabinet sebagai sebuah organisasi pemerintahan yang di dalamnya terdapat dewan-dewan menteri, di mana memiliki tugas dan fungsi dalam penyelenggaraan pemerintahan. Sebagai negara dengan menerapkan sistem pemerintahan yang langsung dikepalai oleh Presiden, maka Negara Indonesia mempunyai komposisi kabinet yang bertanggung jawab secara langsung kepada Presiden.

Mengingat wilayah Indonesia yang sangat luas, UUD 1945 telah memberikan landasan konstitusional mengenai penyelenggaraan pemerintahan daerah di Indonesia, dengan menempatkan Kabinet dalam Pemerintahan Pusat untuk dapat saling berkoordinasi dengan satuan Pemerintah Daerah yang dikepalai oleh Kepala Daerah. Dengan demikian, hubungan antara Pemerintah Pusat dan Pemerintah Daerah memiliki 4 (empat) dimensi penting untuk dicermati, yaitu meliputi hubungan kewenangan, kelembagaan, keuangan, dan pengawasan. Pembagian kewenangan untuk menyelenggarakan urusan-urusan pemerintahan tersebut akan sangat mempengaruhi sejauh mana Pemerintah Pusat dan Pemerintah Daerah memiliki wewenang untuk menyelenggarakan urusan-urusan Pemerintahan. Hal ini, mengingat wilayah kekuasaan Pemerintah Pusat meliputi Pemerintah Daerah, maka dalam hal ini yang menjadi obyek yang diurusi adalah sama, namun kewenangannya yang berbeda.

Hubungan pengawasan merupakan konsekuensi yang muncul dari pemberian kewenangan, agar terjaga keutuhan Negara Kesatuan. Selain diatur dalam UU Nomor 23 Tahun 20014 tentang Pemerintah Daerah, juga pengaturan dalam berbagai UU sektoral yang pada kenyataannya masing-masing tidak sama dalam pembagian kewenangannya. Pengaturan yang demikian menunjukkan bahwa tarik menarik hubungan Kabinet sebagai kepanjangan tangan Pemerintah Pusat serta Kepala Daerah sebagai bagian dari Pemerintah Daerah, kemudian memunculkan apa yang oleh Bagir Manan disebut dengan spanning ${ }^{2}$ antara Pemerintah Pusat dan Pemerintah Daerah.

Dengan mengidentifikasi adanya berbagai bentuk kewenangan yang saling tumpah-tindih antar instansi pemerintahan dan aturan yang berlaku, baik aturan di tingkat pusat dan/atau peraturan di tingkat daerah. Hal tersebut terutama berhubungan dengan a) otoritas terkait tanggung jawab pemerintah pusat dan daerah; b) kewenangan yang didelegasikan dan fungsi-fungsi yang disediakan oleh Departemen kepada daerah; dan c) kewenangan yang dalam menyusun standar operasional prosedur bagi daerah dalam menerjemahkan setiap peraturan perundangundangan yang ada.

1. Jimly Asshiddiqie, (2007), Pokok-pokok Hukum Tata Negara Indonesia Pasca Reformasi, Jakarta: Bhuana Ilmu Populer, hlm. 311.

2. Bagir Manan, (1994), Hubungan Antara Pusat dan Daerah Menurut UUD 1945, Jakarta: Pustaka Sinar Harapan, hlm. 22. 
Permasalahan yang hangat terkait dengan hubungan antara Kabinet sebagai pelaksana Pemerintah Pusat dengan Kepala Daerah sebagai pemegang kedaulatan Pemerintah Daerah. Antara Menteri Hukum dan Hak Asasi Manusia, Yasona Laoly, berseteru dengan Walikota Tangerang, Arief Rachadiono Wismansyah. Adapun permasalahan yakni terkait dengan keberadaan Gedung Politeknik Ilmu Pemasyarakatan dan Politeknik Imigrasi, di Kota Tangerang. Wali Kota Tangerang, Arief Rachadiono Wismansyah, menghentikan pelayanan publik di lahan Kemenkumham. Alasannya, lahan tempat pendidikan tersebut adalah lahan yang masuk dalam Ruang Terbuka Hijau (RTH).

Selain sengketa kewenangan lahan yang banyak terjadi antara Pemerintah Pusat dengan Pemerintah Daerah, juga masalah regulasi di daerah menjadi permasalahan, di mana Pemerintah Pusat telah mencabut 3.143 Peraturan Daerah (Perda) yang dianggap bermasalah. Adapun kategori Perda yang dianggap bermasalah tersebut adalah peraturan yang menghambat pertumbuhan ekonomi daerah dan memperpanjang jalur birokrasi. Perda yang dianggap menghambat proses perizinan dan investasi serta menghambat kemudahan berusaha. Bahkan, ada Perda yang diklaim pemerintah telah bertentangan dengan peraturan perundangan yang lebih tinggi dan tidak mencerminkan toleransi antar sesama penduduk di daerah, juga akan dicabut oleh pemerintah melalui Menteri Dalam Negeri. ${ }^{3}$ Maka, harmonisasi dalam peraturan perundang-undangan di tingkat pusat dan daerah, sebagai salah satu agenda yang menjadi prioritas Pemerintah Pusat.

Menurut Pratikno, bahwa pentingnya prinsip dasar demokratisasi dalam pengelolaan konflik antara pusat-daerah, sangat tergantung kepada, pertama, seberapa jauh demoratisasi nasional dan demokrasi lokal nerhasil dikembangkan dan seberapa jauh demokratisasi nasional dan demokrasi lokal bisa diintegrasikan dalam prosesdur demokrasi nasional. Kedua, sejauh mana demokrasi nasional yang dibangun berdasarkan demokrasi lokal tersebut menciptakan eksistensi masyarakat lokal secara politik, ekonomi dan kultur dalam masayarakat politik nasional. Ketiga, sejauh mana manajemen pemerintahan melakukan distribusi sumber daya ekonomi, politik dan ekonomi lintas lokalitas sehingga tetap relevan mendukung negara-negara bangsa. Sedangkan, Syamsuddin Haris, lebih menekankan pada penataan kembali hubungan pusat-daerah yang lebih harmonis dengan didasarkan pada kemitraan dan saling ketergantungan. ${ }^{4}$

Pelaksanaan pemerintahan tentu diharapkan tidak menghilangkan sistem hukum nasional. Bagaimanapun, derajat hubungan pusat dan daerah dapat dijadikan sebagai indikasi pada posisi mana struktur suatu negara berada. Meski demikian, tidak mungkin terdapat suatu negara yang sangat bersifat unitaris atau sebaliknya sangat bersifat federalis. Heinz Laufer dan Munch Ursula mengemukakan, bahwa elemen hubungan antara pusat dan daerah tidak bersifat monosentris, melainkan polisentris bergerak dari suatu kontinum ke kontinum lainnya, dari kontinum unitaris ke kontinum federalis atau sebaliknya. $^{5}$

Dalam pergerakan kontinum tersebut, Eko Prasojo, ${ }^{6}$ mengemukakan tugas berat setiap negara bangsa yang harus diselesaikan oleh para pembuat keputusan politik adalah menjaga keseimbangan antara gerakan yang bersifat sentrifugal ${ }^{7}$ dengan gerakan yang bersifat sentripetal ${ }^{8}$. Kekuatan sentrifugal yang terlalu besar akan mengakibatkan gerakan sepatisme yang mungkin berakibat pada disintegrasi bangsa. Sedangkan, kekuatan sentripetal

3. Andryan, Pencabutan Perda, Harian Waspada, Senin 27 Juni 2016.

4. Syamsuddin Haris (ed), (2007), Desentralisasi dan Otonomi Daerah (Desentralisasi, Demokratisasi dan Akuntabilitas Pemerintahan Daerah), Jakarta: LIPI Press, hlm. vii.

5. https://www.saldiisra.web.id/index.php/buku-jurnal/jurnal/19-jurnalnasional/336-pembagian-kewenanganpusat-daerah-dalam-undang-undang-nomor-11-tahun-2006-tentang-pemerintahan-aceh.html. Di akses pada tanggal 25 Juli 2019

6. Ibid.

7. Kekuasaan sentrifugal sifatnya memusat atau berpusat (centrifugal forces), maka rawan terjadi penyelewengan kekuasaan.

8. Kekuasaan sentripetal merupakan negara yang membuat administrasi negara hanya terfokus pada organisasi dan manajemen internal dari kegiatan pemerintah. Misalnya anggaran negara, manajemen kepegawaian, dan pelayanan jasa. 
yang berlebihan akan menciptakan pemerintahan yang berkarakter sentralistis, di mana diskresi dan partisipasi lokal dapat terabaikan.

Otonomi daerah bertujuan untuk meningkatkan partisipasi masyarakat dan akuntabilitas penyelenggaraan pemerintah. Banyaknya urusan yang diserahkan kepada kabupaten/kota tidak diikuti dengan kemampuan dan jumlah sumber daya manusia (SDM) aparatur yang tersedia. Terbatasnya kualititas dan jumlah SDM aparatur merupakan masalah utama yang dihadapi oleh Pemerintah Daerah sangat dirasakan dalam pelayanan maupun dalam pengelolaan keuangan daerah. Di sisi lain peran dan fungsi Kepala Daerah sebagai wakil pemerintahan pusat juga tidak berjalan efektif, sehingga SDM aparatur tidak dapat didistribusikan secara merata kepada Pemerintah Daerah lainnya. ${ }^{9}$

Dengan berbagai permasalahan tersebut, menghendaki adanya perubahan antara hubungan antara pusat dan daerah. Dengan kata lain, menurut Eko Parsojo ${ }^{10}$, perlu dipikirkan konstruksi baru hubungan antara pusat dan daerah. Tidak akan terjalinnya harmonisasi antara Kabinet dengan Pemerintah Daerah sebagai bentuk penguatan sistem pemerintahan presidensial, apabila masih banyaknya permasalahan yang tidak dapat diselesaikan tersebut. Konstruksi hubungan tersebut setidaknya memuat pemikiran ulang mengenai tingkatan pemerintahan, status dan kedudukannya; pembagian wewenang (atau urusan) antar berbagai tingkatan pemerintahan; perimbangan keuangan antar tingkatan pemerintahan; partisipasi daerah dalam pembuatan keputusan di tingkat nasional; dan intervensi pusat terhadap daerah.

\section{B. Pembahasan}

\section{B.1. Konsepsi Negara Kesatuan dalam UUD 1945}

Ketentuan UUD 1945 sebagaimana dirumuskan dalam Pasal 1 ayat (1), dinyatakan bahwa Negara Indonesia adalah Negara Kesatuan yang berbentuk republik. Negara Kesatuan merupakan sistem kenegaraan yang menetapkan seluruh wilayah negara, tanpa kecuali, merupakan kesatuan wilayah administrasi dan hukum. ${ }^{11}$ Prinsip Negara Kesatuan ialah pemegang kekuasaan tertinggi atas seluruh urusan Negara adalah pemerintah pusat tanpa ada suatu delegasi atau pelimpahan kewenangan kepada pemerintahan daerah atau urusan pemerintahan tidak dibagi-bagi antara pemerintah pusat dan pemerintah daerah, sehingga urusan-urusan Negara dalam Negara Kesatuan tetap merupakan suatu kebulatan dan pemegang kekuasaan tertinggi di Negara adalah pemerintah pusat.

Negara Kesatuan memulai segala sesuatunya dari prinsip manajemen pemerintahan yang bersifat sentralistik. Hal ini terbaca dari struktur pemerintahannya yakni bersifat monopoli yang ditekankan pada besar dan kuatnya kekuasaan pemerintah pusat atas pemerintah daerah. ${ }^{12}$ Kesadaran bahwa pola manajemen sentralistik cenderung tidak efektif dan bersifat kontraproduktif terhadap apa yang sebelumnya diperkirakan. Perlunya mengubah pola sentralistik ke desentralistik, banyak dianut oleh negara yang menganut prinsip Negara Kesatuan. Penerapan pola desentralistik pemerintahan dan dekonsentrasi kekuasaan tidak lagi didasarkan atas proses tarik-menarik antara pusat dan daerah, melainkan oleh kebutuhan bersama bahwa hanya melalui desentralisasi kekuasaan pengelolaan pemerintah bisa menjadi lebih efektif dan efesien. Walaupun demikian, desentralisasi tetap tidak mengubah esensi dasar Negara Kesatuan. ${ }^{13}$ Sistem pemerintahan Indonesia menganut asas Negara Kesatuan yang didesentralisasikan (otonomi), dengan demikian maka ada tugas-tugas tertentu yang diurus oleh pemerintah daerah sendiri.

Pemerintah pusat telah merasakan bahwa sistem manajemen yang terpusat lebih merupakan beban karena segala sesuatu yang menyangkut urusan pemerintah selalu menunggu arahan

9. Yappika, (2006), disadur dari "Laporan akhir sosialisasi Pemehaman\& Sosialisasi Penyusunan RUU Tata Hubungan Kewenangan Pemerintah Pusat \& Daerah”, Kementerian Negara PAN berkerjaama dengan Pusat Kajian Administrasi Daerah dan Kota, FISIP UI, Depok, 2006.

10. Eko Parsojo, (2006), Konstruksi Ulang Hubungan Pemerintah Pusat dan Pemerintah Daerah di Indonesia: Antara Sentripetalisme dan Sentrifugalisme, Pidato Pengukuhan sebagai Guru Besar Tetap FISIP UI, Depok, 2006, hlm. 25.

11. Hendarmin Ranadireksa, (2007), Arsitektur Konstitusi Demokratik, Bandung: Fokusmedia, hlm. 59.

12. Ibid. hlm. 60 .

13. Ibid. hlm. 62 . 
pemerintah pusat. Terlebih dengan wilayah yang sangat luas, pemerintah pusat akan selalu merasa kesulitan mengontrol pelaksanaan dan efektifitas kebijakan khususnya pada daerah yang berlokasi paling jauh dari pusat, begitu pun sebaliknya dengan daerah. Oleh karenanya, penerapan otonomi luas, tidak sekedar dilihat dari sisi kepentingan daerah, tetapi juga kebutuhan pusat untuk "berbagi beban". Maka, pola desentralistik dengan memberikan otonomi ${ }^{14}$ luas kepada daerah merupakan prinsip manajemen pemerintahan yang rasional. ${ }^{15}$

Ateng Syafrudin, yang menyatakan bahwa latar belakang Negara Kesatuan menganut sistem desentralisasi adalah luas wilayah, makin banyaknya tugas yang harus diurus oleh pemerintah pusat, adanya perbedaan daerah yang satu dengan yang lain yang sukar diatur dan diurus secara sama (uniform) oleh pemerintah pusat. Lebih lanjut Ateng Syafrudin menambahkan, dalam konstitusi tiap negara memberikan kewenangan pemerintah negara kepada satu pemerintah, yaitu pemerintah pusat, karena penyelenggaraan segala kepentingan hak baik dari pusat maupun dari daerah sebenarnya adalah kewajiban dari pemerintah pusat. Hanya berhubungan dengan luasnya daerah, makin banyak tugas yang harus diurus oleh pemerintah pusat, sejalan dengan kemajuan masyarakat dan negara, perbedaan antara yang satu dengan yang lain yang sukar diketahui dan sukar diatur secara memusat, maka jika keadaan daerah-daerah sudah memungkinkan, pusat menyerahkan kepada daerah untuk mengurus dan menyelenggarakan sendiri kebutuhan-kebutuhan khusus dari daerah-daerah itu. Penyerahan itu dapat diperluas tetapi dapat pula dipersempit oleh pemerintah pusat dengan memperhatikan kepentingan nasional disatu pihak dan memperhatikan kemampuan daerah berkepentingan di lain pihak. ${ }^{16}$

UUD 1945 beserta perubahannya telah memberikan landasan konstitusional mengenai penyelenggaraan pemerintahan daerah di Indonesia. Di antara ketentuan tersebut yaitu: 1) prinsip pengakuan dan penghormatan negara terhadap kesatuan-kesatuan masyarakat hukum adat serta hak-hak tradisionalnya sepanjang masih hidup dan sesuai dengan perkembangan masyarakat dan prinsip Negara Kesatuan Republik Indonesia; ${ }^{17}$ 2) Prinsip daerah mengatur dan mengurus sendiri urusan pemerintahan menurut asas otonomi dan tugas pembantuan2; 3) prinsip menjalankan otonomi seluas-luasnya; 4 ) prinsip mengakui dan menghormati pemerintahan daerah yang bersifat khusus dan istimewa; 5) prinsip badan perwakilan dipilih langsung dalam suatu pemilu; 6) prinsip hubungan pusat dan daerah harus dilaksanakan secara selaras dan adil; 7) prinsip hubungan wewenang antara pemerintah pusat dan pemerintah daerah harus memperhatikan kekhususan dan keragaman daerah; 8) prinsip hubungan keuangan, pelayanan umum, pemanfatan sumber daya alam dan sumber daya lainnya antara pemerintah pusat dan pemerintahan daerah dilaksanakan secara adil dan selaras berdasarkan undang-undang; dan 9) prinsip pengakuan dan penghormatan negara terhadap satuan-satuan pemerintahan daerah yang bersifat khusus atau bersifat istimewa.

Sebagai pelaksanaan lebih lanjut dari dasar konstitusional tersebut, satuan pemerintahan di bawah pemerintah pusat yaitu daerah provinsi dan kabupaten/kota memiliki urusan yang bersifat wajib dan pilihan. Provinsi memiliki urusan wajib dan urusan pilihan. Selain itu ditetapkan pula kewenangan pemerintah Pusat menjadi urusan Pemerintahan yang meliputi: a) politik luar negeri; b) pertahanan; c) keamanan; d) yustisi; e) moneter dan fiskal nasional; dan f) agama. Meskipun dengan ketentuan pemberlakuan otonomi seluas-luasnya dalam UUD 1945, namun muncul pula pengaturan dalam Peraturan Pemerintah Nomor 38 tahun 2007 yang membagi urusan pemerintahan antara pemerintah, pemerintahan daerah provinsi, dan pemerintahan daerah kabupaten/kota.

Secara prinsip, terdapat perbedaan pola pembagian kekuasaan atau kewenangan antara Negara

14. Hans Kelsen, mengatakan bahwa otonomi daerah adalah suatu perpaduan langsung dari ide-ide desentralisasi dengan ide-ide demokrasi. Organ-organ pembuat norma-norma daerah dipilih oleh para subyek dari norma-norma itu. 15. Ibid. hlm. 63

16. Ateng Syafrudin, (1993), Pengaturan Koordinasi Pemerintahan Di Daerah, Bandung: Citra Aditya Bakti, hlm. 193. 17. Pasal 18 B ayat (2) UUD 1945 
Kesatuan dan Negara Federal. Pada Negara Federal, kekuasaan atau kewenangan berasal dari bawah atau dari daerah/Negara bagian yang bersepakat untuk menyerahkan sebagian kewenangannya kepada pemerintah Federal, yang biasanya secara eksplisit tercantum dalam konstitusi Negara Federal. Kewenangan pemerintah pusat dengan demikian akan menjadi terbatas atau limitatif dan daerah memiliki kewenangan luas. Sedangkan pada Negara Kesatuan, kewenangan pada dasarnya berada atau dimiliki oleh pemerintah pusat yang kemudian diserahkan atau dilimpahkan kepada daerah. Penyerahan atau pelimpahan kewenangan atau urusan pada Negara Kesatuan biasanya dibuat secara eksplisit, dengan demikian daerah mempunyai kewenangan terbatas.

Adapun prinsip pembagian kekuasaan/ kewenangan atau urusan pada Negara Kesatuan adalah sebagai berikut: Pertama, kekuasaan atau kewenangan pada dasarnya adalah milik pemerintah pusat, daerah diberi kewenangan atau hak mengelola dan menyelenggarakan sebagian kewenangan pemerintah yang dilimpahkan atau diserahkan. Jadi proses penyerahan atau pelimpahan kewenangan. Kedua, Pemerintah pusat dan pemerintah daerah tetap mempunyai garis komando dan hubungan hierarkis. Hubungan yang dilakukan oleh pemerintah pusat tidak untuk mengintervensi dan mendikte pemerintah daerah dalam berbagai hal. Ketiga, kewenangan atau kekuasaan yang dialihkan atau diserahkan kepada daerah dalam kondisi tertentu, di mana daerah tidak mampu menjalankan tugas dengan baik, maka kewenangan atau urusan yang dilimpahkan atau diserahkan tersebut dapat ditarik kembali oleh pemerintah pusat sebagai pemilik kekuasaan atau kewenangan tersebut.

\section{B.2.Pola Hubungan Pemerintah Pusat dengan Pemerintah Daerah}

Saldi Isra ${ }^{18}$, menyatakan bahwa dalam teori ketatanegaraan, Negara Kesatuan (unitary state) merupakan negara yang sifatnya tunggal, kedaulatan hanya ada pada 1 (satu) tangan yaitu pemerintahan pusat dan tidak terdiri dari kumpulan negara-negara. Salah pandangan yang paling umum dirujuk dalam mengemukakan negara kesatuan adalah pendapat CF. Strong (1966: 84) yang mengatakan:

...the essence of a unitary state is that the sovereignty is undivided, or, in order words, that the powers of the central government are unrestricted, for the constitution of unitary state does not admit of any other law-making body than the central one.

Berdasarkan pendapat tersebut, karakter yang melekat pada Negara Kesatuan yaitu supremasi dari parlemen pusat (the supremacy of the central parliament) dan tidak adanya badan-badan lain yang berdaulat (the absence of subsidiary sovereign bodies). Dari pendapat tersebut, kekuasaan pusat menjadi begitu sentral dalam menentukan perkembangan politik di semua level pemerintahan. ${ }^{19}$

Salah satu perubahan besar dalam hubungan pusat dan daerah adalah dianutnya prinsip residu power (pembagian kewenangan sisa) dalam penataan hubungan pusat-daerah. Salah satunya, kewenangan daerah otonom mencakup kewenangan dalam seluruh bidang pemerintahan, kecuali kewenangan dalam bidang politik luar negeri, pertahanan keamanan, peradilan, moneter dan fiskal, agama, serta kewenangan bidang lain. ${ }^{20}$ Berdasarkan ketentuan yang terdapat dalam UU No.23 Tahun 2014 tentang Pemerintah Daerah, salah satu masalah yang dihadapi dalam implementasi otonomi daerah yang berakar dari konstruksi hubungan pusat dan daerah adalah ketidakjelasan model pembagian kewenangan antar tingkat pemerintahan.

Ketidakejelasan model pembagian kewenangan ini, dalam praktiknya terefleksi dalam 2 (dua) wajah. Pertama, untuk sektor-sektor yang bersifat profit seringkali terjadi tumpang tindih antara pusat, provinsi dan kabupaten/kota. Kedua, untuk sektorsektor yang bersifat pembiayaan, seringkali terjadi kevakuman kewenangan. ${ }^{21}$ Saldi Isra menggambarkan wajah praktik hubungan pusat dan daerah di atas berakar dari upaya mereduksi pasal-pasal yang

18. "Saldi Isra, Pembagian Kewenangan Pusat-Daerah dalam Perspektif Undang-Undang Pemerintahan Aceh, Makalah, diselenggarakan oleh Forum LSM Aceh bekerja sama dengan Forbes BRA, di Banda Aceh, 22 Novemver 2006.

19. Ibid.

20. Ibid.

21. Eko Parsojo, 2006, Konstruksi Ulang Hubungan Pemerintah Pusat dan Pemerintah Daerah di Indonesia: Antara Sentripetalisme dan Sentrifugalisme, Pidato Pengukuhan sebagai Guru Besar Tetap FISIP UI, Depok, hlm. 25. 
mengatur prinsip residu power dengan aturan-aturan lain yang setingkat (baik internal maupun eksternal) atau dengan peraturan yang lebih rendah.

Dasar pelaksanaan otonomi daerah di Indonesia sesuai UUD 1945 terdapat 2 (dua) nilai dasar yang dikembangkan yakni, nilai unitaris dan nilai desentralisasi. Nilai dasar unitaris diwujudkan dalam pandangan bahwa Indonesia tidak akan mempunyai kesatuan pemerintahan lain di dalamnya yang bersifat negara, artinya kedaulatan yang melekat pada rakyat, bangsa dan Negara Republik Indonesia tidak akan terbagi di antara kesatuan-kesatuan pemerintahan regional atau lokal. Sementara itu, nilai dasar desentralisasi diwujudkan dengan pembentukan daerah otonom dan penyerahan kewenangan untuk menyelenggarakan urusanurusan pemerintahan yang telah diserahkan atau diakui sebagai domain rumah tangga daerah otonom tersebut.

Dikaitkan dengan 2 (dua) nilai dasar konstitusi tersebut, penyelenggaraan desentralisasi di Indonesia terkait erat dengan pola pembagian kewenangan antara Pemerintah Pusat dan Pemerintah Daerah. $\mathrm{Hal}$ ini karena dalam penyelenggaraan desentralisasi selalu terdapat 2 (dua) elemen penting, yakni pembentukan daerah otonom dan penyerahan kewenangan secara hukum dari pemerintah pusat ke pemerintah daerah untuk mengatur dan mengurus bagian-bagian tertentu urusan pemerintahan.

Sesuai UUD 1945, mengingat Indonesia adalah "Eenheidstaat"22, maka di dalam lingkungannya tidak dimungkinkan adanya daerah yang bersifat staat juga. Ini berarti bahwa sebagai pembatas besar dan luasnya daerah otonom dan hubungan kewenangan antara pemerintah pusat dan daerah adalah menghindari daerah otonom menjadi negara dalam negara. Dengan demikian pembentukan daerah otonom dalam rangka desentralisasi di Indonesia memiliki ciri-ciri:

a. Daerah Otonom tidak memiliki kedaulatan atau semi kedaulatan layaknya di negara federal;

b. Desentralisasi dimanisfestasikan dalam bentuk penyerahan atas urusan pemerintahan;

c. Penyerahan urusan pemerintahan sebagaimana dimaksud pada butir b, tersebut di atas utamanya terkait dengan pengaturan dan pengurusan kepentingan masyarakat setempat (lokalitas) sesuai dengan prakarsa sendiri berdasarkan aspirasi masyarakat.

Muhammad Yamin tidak menghendaki pola hubungan yang serba-pusat alias sentralisitik. Baginya, pola hubungan pusat-daerah dibangun dengan menjaga kepentingan daerah; pembagian kekuasaan antara badan pusat dan badan daerah haruslah diatur dengan keadilan dan bijaksana sehingga tetap menjaga keistimewaan. Gagasan Yamin ini sama dengan gagasan pendiri bangsa lain, misalnya, Soepomo menyatakan daerah-daerah kecil yang mempunyai susunan rakyat asli seperti desa (Jawa), nagari (Minangkabau), dusun dan marga (Palembang), huta dan kuria (Tapanuli), gampong (Aceh) tetap dipertahankan posisi keistimewaannya. Para pendiri bangsa termasuk Yamin dengan tegas menolak dilakukan penyeragaman seperti praktik yang pernah dilakukan Orde Baru. Semua ini tidak terlepas dari bentangan fakta yang hidup di sejumlah daerah sebelum kemerdekaan. Fakta tersebut membuktikan ketajaman visi bernegara mereka ketika menawarkan berbagai pilihan design hubungan pusat-daerah. ${ }^{23}$

Berdasarkan UUD 1945, bentuk negara yang digunakan di Indonesia adalah bentuk negara kesatuan yang menganut asas desentralisasi. Pasal 1 Ayat (1) UUD 1945 menyatakan, Negara Indonesia adalah Negara Kesatuan yang berbentuk Republik. Penggunaan asas desentralisasi dalam NKRI ditunjukan dengan adanya pembagian daerah sebagaimana tertuang dalam Pasal 18 Perubahan Kedua UUD 1945 yang menyatakan:

(1) Negara Kesatuan Republik Indonesia dibagi atas daerah- daerah Propinsi dan daerah-daerah Propinsi itu dibagi atas Kabupaten dan Kota, yang tiap-tiap Propinsi, Kabupaten dan Kota mempunyai pemerintahan daerah yang diatur dengan Undang-Undang;

(2) Pemerintah Daerah Propinsi, Daerah Kabupaten dan Kota mengatur dan mengurus sendiri urusan pemerintahan menurut asas otonomi dan tugas pembantuan.

22. Nilai yang bersifat negara, berarti kedaulatan yang melekat pada rakyat, bangsa dan negara Republik Indonesia tidak akan terbagi di antara kesatuan-kesatuan pemerintahan

23. Saldi Isra, Gagasan Bernegara Yamin, Majalah Tempo, 2 September 2014. 
(3) $\ldots$

(4) $\ldots$

(5) Pemerintahan daerah menjalankan otonomi seluas-luasnya, kecuali urusan pemerintahan yang oleh undang-undang ditentukan sebagai urusan Pemerintah Pusat.

(6) Pemerintahan daerah berhak menetapkan peraturan daerah dan peraturan-peraturan lain untuk melaksanakan otonomi dan tugas pembantuan.

(7) Susunan dan tata cara penyelenggaraan pemerintahan daerah diatur dalam undangundang.

Selanjutnya Pasal 18A UUD 1945 menyatakan:

(1) Hubungan wewenang antara pemerintah pusat dan pemerintahan daerah provinsi, kabupaten, dan kota, atau antara provinsi dan kabupaten dan kota, diatur dengan undang-undang dengan memperhatikan kekhususan dan keragaman daerah.

(2) Hubungan keuangan, pelayanan umum, pemanfaatan sumber daya alam dan sumber daya lainnya antara pemerintah pusat dan pemerintahan daerah diatur dan dilaksanakan secara adil dan selaras berdasarkan undangundang.

Terakhir, Pasal 18B UUD 1945 menyatakan:

(1) Negara mengakui dan menghormati satuansatuan pemerintahan daerah yang bersifat khusus atau bersifat istimewa yang diatur dengan undang-undang.

(2) Negara mengakui dan menghormati kesatuankesatuan masyarakat hukum adat beserta hakhak tradisionalnya sepanjang masih hidup dan sesuai dengan perkembangan masyarakat dan prinsip Negara Kesatuan Republik Indonesia, yang diatur dalam undang-undang.

Sebagai negara yang juga memberikan pemerintahan di daerah, maka konsep desentralisasi merupakan instrumen untuk mencapai tujuan bernegara dalam kerangka kesatuan bangsa (national unity) yang demokratis (democratic government). Dalam konteks UUD 1945, selalu harus diperhatikan keseimbangan antara kebutuhan untuk menyelenggarakan desentralisasi dengan kebutuhan memperkuat kesatuan nasional. Ciri umum penyelenggaraan desentralisasi di Indonesia sesuai dengan UUD 1945 adalah:

1) Pemerintahan Daerah merupakan hasil pembentukan oleh Pemerintah, bahkan dapat dihapus oleh Pemerintah melalui proses hukum apabila daerah tidak mampu menjalankan otonominya setelah melalui fasilitasi pemberdayaan;

2) Dalam rangka desentralisasi, di wilayah Indonesia dibentuk Provinsi dan di wilayah Provinsi dibentuk Kabupaten dan Kota sebagai daerah otonom;

3) Sebagai Konsekuensi cirri butir 1 dan 2, maka kebijakan desentralisasi disusun dan dirumuskan oleh Pemerintah, sedangkan penyelenggaraan otonomi daerah dilaksanakan oleh Pemerintah Daerah dan Dewan Perwakilan Rakyat Daerah dengan melibatkan masyarakat sebagai cerminan pemerintahan yang demokratis;

4) Hubungan antara pemerintah daerah otonom dengan pemerintah nasional (Pusat) adalah bersifat tergantung (dependent) dan bawahan (sub-ordinate). Hal ini berbeda dengan hubungan antara pemerintah Negara bagian dengan pemerintah federal yang menganut federalisme, yang bersifat independen dan koordinatif;

5) Penyelengggaraan desentralisasi menuntut persebaran urusan pemerintahan oleh pemerintah kepada daerah otonom sebagai badan hukum publik. Urusan pemerintahan yang didistribusikan hanyalah merupakan urusan pemerintahan yang menjadi kompetensi Pemerintah dan tidak mencakup urusan yang menjadi kompetensi Lembaga Negara yang membidangi legislatif atau Lembaga pembentuk Undang-Undang dan Yudikatif ataupun lembaga Negara yang berwenang mengawasi keuangan Negara. Penyelenggaraan urusan pemerintahan daerah yang didesentralisasikan menjadi kewenangan Kepala Daerah dan DPRD untuk melaksanakannya sesuai dengan mandat yang diberikan rakyat.

\section{B.3. Penguatan Sistem Pemerintahan}

Istilah sistem pemerintahan berasal dari gabungan 2 (dua) kata sistem dan pemerintahan. Kata sistem merupakan terjemahan dari kata system 
(bahasa Inggris) yang berarti susunan, tatanan, jaringan, atau cara. Sedangkan, pemerintahan berasal dari kata pemerintah, dan yang berasal dari kata perintah. Kata Perintah dalam Kamus Bahasa Indonesia, kata-kata itu berarti:

a) Perintah adalah perkataan yang bermakna menyuruh melakukan sesuatu;

b) Pemerintah adalah kekuasaan yang memerintah suatu wilayah, daerah, atau, Negara;

c) Pemerintahan adalah perbuatan, cara, hal, urusan dalam memerintah.

Pengertian pemerintahan dalam arti luas adalah perbuatan memerintah yang dilakukan oleh badanbadan legislatif, eksekutif, dan yudikatif di suatu Negara dalam rangka mencapai tujuan penyelenggaraan negara, sedangkan dalam arti sempit, pemerintahan adalah perbuatan memerintah yang dilakukan oleh badan eksekutif beserta jajarannya dalam rangka mencapai tujuan penyelenggaraan negara. Dengan demikian, pengertian Sistem Pemerintahan adalah sebagai suatu tatanan utuh yang terdiri atas berbagai komponen pemerintahan yang bekerja saling bergantungan dan mempengaruhi dalam mencapai tujuan dan fungsi pemerintahan.

Istilah sistem pemerintahan merupakan gabungan dari 2 (dua) kata, yaitu: "sistem" dan “pemerintahan". Sistem berarti berarti keseluruhan yang terdiri dari beberapa bagian yang mempunyai hubungan fungsional baik antara bagianbagian maupun hubungan fungsional terhadap keseluruhannya, sehingga hubungan tersebut menimbulkan suatu ketergantungan antara bagianbagian yang akibatnya jika salah satu bagian tidak bekerja dengan baik akan mempengaruhi keseluruhannya itu. Dan pemerintahan dalam arti luas mempunyai pengertian segala urusan yang dilakukan negara dalam menyelenggarakan kesejahteraan rakyatnya dan kepentingan negara itu sendiri. Dari pengertian itu, maka secara harfiah sistem pemerintahan dapat diartikan sebagai suatu bentuk hubungan antar lembaga negara dalam menyelenggarakan kekuasaan-kekuasaan negara untuk kepentingan negara itu sendiri dalam rangka untuk mewujudkan kesejahteraan rakyatnya.
Sistem pemerintahan diartikan (konsep trias politica) sebagai suatu tatanan utuh yang terdiri atas berbagai komponen pemerintahan yang bekerja saling bergantungan dan mempengaruhi dalam mencapaian tujuan dan fungsi pemerintahan. Kekuasaan dalam suatu Negara diklasifikasikan menjadi 3 (tiga), yaitu Kekuasaan Eksekutif yang berarti kekuasaan menjalankan undang-undang atau kekuasaan menjalankan pemerintahan; Kekuasaan Legislatif yang berarti kekuasaan membentuk undang-undang; dan Kekuasaan Yudikatif yang berarti kekuasaan mengadili terhadap pelanggaran atas undang-undang.

Komponen-komponen tersebut secara garis besar meliputi lembaga eksekutif, legislatif dan yudikatif. Jadi, sistem pemerintahan negara menggambarkan adanya lembaga-lembaga negara, hubungan antarlembaga negara, dan bekerjanya lembaga negara dalam mencapai tujuan pemerintahan negara yang bersangkutan. Sedangkan tujuan pemerintahan negara pada umumnya didasarkan pada cita-cita atau tujuan negara. Misalnya, tujuan pemerintahan negara Indonesia adalah melindungi segenap bangsa Indonesia dan untuk memajukan kesejahteraan umum, mencerdaskan kehidupan bangsa, serta ikut melaksanakan ketertiban dunia yang berdasarkan kemerdekaan, perdamaian abadi dan keadilan sosial. Sehingga lembaga-lembaga yang berada dalam satu sistem pemerintahan Indonesia bekerja secara bersama dan saling menunjang untuk terwujudnya tujuan dari pemerintahan di negara Indonesia. Dengan demikian dapat disimpulkan sistem pemerintahan negara adalah sistem hubungan dan tata kerja antar lembaga-lembaga negara dalam rangka penyelenggaraan negara.

\section{a) Model Sistem Pemerintah}

Miriam Budiardjo membedakan sistem pemerintahan ke dalam 2 (dua) kelompok, yaitu: Sistem parlementer (parliamentary executive) dan sistem presidensil dengan xed executive atau non parliamentary executive. ${ }^{24}$ Pada umumnya, negaranegara di dunia menganut salah satu dari sistem pemerintahan tersebut. Adanya sistem pemerintahan lain dianggap sebagai variasi atau kombinasi dari 2 (dua) sistem pemerintahan di atas. Negara

24. Miriam Budardjo, (2009), Dasar-Dasar Ilmu Politik, Jakarta: Gramedia Pustaka Utama, hlm. 301. 
Inggris dianggap sebagai tipe ideal dari negara yang menganut sistem pemerintahan parlemen. Bahkan, Inggris disebut sebagai Mother of Parliaments (induk parlemen), sedangkan Amerika Serikat merupakan tipe ideal dari negara dengan sistem pemerintahan presidensial. Kedua negara tersebut disebut sebagai tipe ideal karena menerapkan ciri-ciri yang dijalankannya. Inggris adalah negara pertama yang menjalankan model pemerintahan parlementer. Amerika Serikat juga sebagai pelopor dalam sistem pemerintahan presidensial. Kedua negara tersebut sampai sekarang tetap konsisten dalam menjalankan prinsip-prinsip dari sistem pemerintahannya. Dari 2 (dua) negara tersebut, kemudian sistem pemerintahan diadopsi oleh negara-negara lain di belahan dunia.

Klasifikasi sistem pemerintahan presidensial dan parlementer didasarkan pada hubungan antara kekuasaan eksekutif dan legislatif. Sistem pemerintahan disebut parlementer apabila badan eksekutif sebagai pelaksana kekuasaan eksekutif mendapat pengawasan langsung dari badan legislatif. Sistem pemerintahan disebut presidensial apabila badan eksekutif berada di luar pengawasan langsung badan legislatif. Untuk lebih jelasnya, berikut ini ciri-ciri, kelebihan serta kekurangan dari sistem pemerintahan parlementer. Ciri-ciri dari sistem pemerintahan parlementer adalah sebagai berikut:

Badan legislatif atau parlemen adalah satusatunya badan yang anggotanya dipilih langsung oleh rakyat melalui pemilihan umum. Parlemen memiliki kekuasaan besar sebagai badan perwakilan dan lembaga legislatif.

Anggota parlemen terdiri atas orang-orang dari partai politik yang memenangkan pemiihan umum. Partai politik yang menang dalam pemilihan umum memiliki peluang besar menjadi mayoritas dan memiliki kekuasaan besar di parlemen.

Pemerintah atau kabinet terdiri dari atas para menteri dan perdana menteri sebagai pemimpin kabinet. Perdana menteri dipilih oleh parlemen untuk melaksakan kekuasaan eksekutif. Dalam sistem ini, kekuasaan eksekutif berada pada perdana menteri sebagai kepala pemerintahan. Anggota kabinet umumnya berasal dari parlemen.
Kabinet bertanggung jawab kepada parlemen dan dapat bertahan sepanjang mendapat dukungan mayoritas anggota parlemen. Hal ini berarti bahwa sewaktu-waktu parlemen dapat menjatuhkan kabinet jika mayoritas anggota parlemen menyampaikan mosi tidak percaya kepada kabinet.

Kepala negara tidak sekaligus sebagai kepala pemerintahan. Kepala pemerintahan adalah perdana menteri, sedangkan kepala negara adalah presiden dalam negara republik atau raja/sultan dalam negara monarki. Kepala negara tidak memiliki kekuasaan pemerintahan. Ia hanya berperan sebagai simbol kedaulatan dan keutuhan negara.

Sebagai imbangan parlemen dapat menjatuhkan kabinet maka presiden atau raja atas saran dari perdana menteri dapat membubarkan parlemen. Selanjutnya, diadakan pemilihan umum lagi untuk membentuk parlemen baru.

\section{b) Sistem Pemerintahan Negara Indonesia Ber- dasarkan UUD 1945}

Dalam konteks Indonesia, salah satu kesepakatan dalam pelaksanaan amandemen UUD 1945 adalah tetap mempertahankan sistem presidensil, sekaligus menyempurnakan agar benar memenuhi ciri-ciri umum sistem presidensial. ${ }^{25}$ Menurut Bagir Manan, sistem presidensial di Indonesia sebelum amandemen UUD 1945, mempunyai ciri-ciri yang hampir mirip dengan sistem di Amerika Serikat dengan beberapa ciri khusus, yaitu: ${ }^{26}$

(a) Presiden RI dipilih oleh badan perwakilan rakyat (MPR).

(b) Presiden RI tunduk dan bertanggung jawab kepada badan perwakilan rakyat (MPR), tetapi tidak tunduk dan bertanggung jawab kepada DPR. Selain itu, Presiden RI dapat diberhentikan oleh MPR.

(c) Presiden RI dapat dipilih kembali tanpa batas setiap 5 (lima) tahun sekali.

(d) Presiden RI bersama-sama DPR menjalankan kekuasaan membentuk undang-undang.

Sistem Presidensial pemerintahan berdasarkan Undang-Undang Dasar 1945 pra amandemen sifatnya tidak murni. Hal ini disebabkan sistem tersebut

25. Jimly Asshiddiqie, (2005), Implikasi Perubahan UUD 1945 Terhadap Pembangunan Hukum Nasional, Jakarta: Mahkamah Konsitusi RI, hlm. 10.

26. Bagir Manan, (1999), Lembaga Kepresidenan, Yogyakarta: Gama Media, hlm. 59. 
bercampur baur dengan elemen-elemen sistem parlementer. Percampuran itu antara lain tercermin dalam konsep pertanggungjawaban Presiden kepada MPR yang termasuk ke dalam pengertian lembaga parlemen, dengan kemungkinan pemberian kewenangan kepadanya untuk memberhentikan Presiden dari jabatanya, meskipun bukan karena alasan hukum.

Mekipun adanya kelemahan, kekuasaan yang besar pada presiden juga ada dampak positifnya yaitu presiden dapat mengendalikan seluruh penyelenggaraan pemerintahan sehingga mampu menciptakan pemerintahan yang kompak dan solid. Sistem pemerintahan lebih stabil, tidak mudah jatuh atau berganti. Konflik dan pertentangan antar pejabat negara dapat dihindari. Namun, dalam praktik perjalanan sistem pemerintahan di Indonesia ternyata kekuasaan yang besar dalam diri presiden lebih banyak merugikan bangsa dan negara dari pada keuntungan yang didapatkannya.

Memasuki masa Reformasi ini, bangsa Indonesia bertekad untuk menciptakan sistem pemerintahan yang demokratis. Untuk itu, perlu disusun pemerintahan yang konstitusional atau pemerintahan yang berdasarkan pada konstitusi. Pemerintah konstitusional bercirikan bahwa konstitusi negara itu berisi:

1. adanya pembatasan kekuasaan pemerintahan atau eksekutif,

2. jaminan atas hak asasi manusia dan hak-hak warga negara.

Berdasarkan hal itu, reformasi yang harus dilakukan adalah melakukan perubahan atau amandemen atas UUD 1945. dengan mengamandemen UUD 1945 menjadi konstitusi yang bersifat konstitusional, diharapkan dapat terbentuk sistem pemerintahan yang lebih baik dari yang sebelumnya. Amandemen atas UUD 1945 telah dilakukan oleh MPR sebanyak 4 (empat) tahap, yaitu pada tahun 1999, 2000, 2001, dan 2002. Berdasarkan UUD 1945 yang telah diamandemen menjadi pedoman bagi sistem pemerintahan Indonesia hingga saat ini.

Adanya perubahan-perubahan baru dalam sistem pemerintahan Indonesia, tidak lain diperuntukan dalam memperbaiki sistem presidensial yang lama. Perubahan baru tersebut, antara lain adanya pemilihan secara langsung, sistem bikameral, mekanisme cheks and balance, dan pemberian kekuasaan yang lebih besar kepada parlemen untuk melakukan pengawasan dan fungsi anggaran. Sekalipun koalisi sistem presidensial dengan kepartaian majemuk menghadirkan banyak kesulitan dan masalah, menilik design sistem pemilu presiden yang berlaku, sulit mengh pembentukan pemerintahan koalisi. Secara konstitusional, Pasal 6A Ayat (2) UUD 1945 membuka ruang adanya koalisi partai politik peserta pemilu. Kemudian, Undang-Undang Tahun 2008 tentang Pemilihan Umum Presiden dan Wakil Presiden, mengharuskan syarat dukungan paling sedikit 20 (dua puluh) persen perolehan kursi di DPR atau 25 (dua puluh lima) persen suara sah nasio pemilu DPR bagi partai politik atau gabungan partai politik untuk mengajukan pasangan calon presiden dan wakil presiden. ${ }^{27}$

Dipandang dari segi praktek, sistem presidensial memang memberikan beberapa keuntungan (dibanding sistem parlementer) yaitu: ${ }^{28}$

(1) stabilitas eksekutif yang didasarkan oleh jaminan terhadap kepastian lamanya jabatan presiden. Hal ini berbeda dengan sistem parlementer yang lebih memungkinkan terjadinya instabilitas eksekutif yang disebabkan oleh besarnya memungkinan penggunaan kekuasaan parlemen untuk menjatuhkan kabinet melalui mosi tidak percaya atau juga tanpa mosi tidak percaya secara formal ketika kabinet telah kehilangan dukungan mayoritas anggota parlemen.

(2) pemilihan umum terhadap presiden dapat dianggap lebih demokratis dari pada pemilihan secara tidak langsung baik formal maupun secara informal sebagaimana eksekutif dalam sistem parlementer.

(3) adanya pemisahan kekuasaan yang berarti pembatasan terhadap kekuasaan eksekutif yang merupakan proteksi yang sangat berharga untuk kebebasan individu terhadap pemerintahan tirani.

27. Saldi Isra, Problematik Koalisi Dalam Sistem Presidensial, Makalah, 2010

28. Arend Lijphart, (2002), Parliamentary versus Presidential Government, New York, Oxford University Press, hlm. 11. 
Selain adanya keuntungan dalam penerapan sistem presidensial, juga adanya kelemahan yang terkandung dalam pola sistem presidensial, yaitu: ${ }^{29}$

(1) konflik antara parlemen dan eksekutif yang dapat menyebabkan kebuntuan (deadlock) dan kelumpuhan. Hal ini dapat saja tidak terhindarkan akibat kedudukan kedua lembaga yang sama-sama independen. Ketika konflik atau ketidaksepakatan terjadi, maka tidak ada institusi yang dapat menyelesaikan masalah tersebut.

(2) kekakuan pemerintahan dalam batas waktu tertentu (temporal rigidity). Hal ini disebabkan oleh masa jabatan Presiden yang tetap dapat menyebabkan proses politik menjadi terhambat dan tidak menyisakan ruang untuk penyesuaian sesuai kebutuhan.

(3) berlakunya sistem "the winner takes all" yang menyebabkan hanya 1 (satu) kandidat dan partai yang menang, dan yang lain kalah. Selain itu, sistem ini menyebabkan Presiden akan susah untuk bernegosiasi atau berkoalisi dengan oposisi jika dalam waktu tertentu muncul masalah yang membutuhkan penyelesaian.

Dalam sistem presidensial dapat disimpulkan beberapa kewenangan Presiden yang biasa dirumuskan dalam UUD berbagai negara, yang mencakup lingkup kewenangan sebagai berikut: ${ }^{30}$

1. Kewenangan yang bersifat eksekutif atau menyelenggarakan pemerintahan berdasarkan UUD (to govern based on the constitution). Bahkan dalam sistem yang lebih ketat, semua kegiatan pemerintahan yang dilakukan oleh presiden haruslah didasarkan atas perintah konstitusi dan peraturan perundang- undangan yang berlaku. Sehingga kecenderungan discretionary power dibatasi sesempit mungkin wilayahnya.

2. Kewenangan yang bersifat legislatif atau untuk mengatur kepentingan umum atau publik (to regulate public affair based on the law and the constitution). Dalam sistem pemisahan kekuasaan (separation of power), kewenangan untuk mengatur ini dianggap ada di tangan lembaga perwakilan, bukan di tangan eksekutif. Jika lembaga eksekutif merasa perlu mengatur, maka kewenangan mengatur di tangan eksekutif itu bersifat derivatif dari kewenangan legislatif. Artinya, Presiden tidak boleh menetapkan suatu peraturan yang bersifat mandiri.

3. Kewenangan yang bersifat judisial dalam rangka pemulihan keadilan yang terkait dengan putusan pengadilan, yaitu untuk mengurangi hukuman, memberikan pengampunan, ataupun menghapuskan tuntutan yang terkait erat dengan kewenangan pengadilan. Dalam sistem parlementer yang mem- punyai kepala negara, ini biasanya mudah dipahami karena adanya peran simbolik yang berada di tangan kepala negara. Tetapi dalam sistem presidensil, kewenangan untuk memberikan grasi, abolisi dan amnesti itu ditentukan berada di tangan Presiden.

4. Kewenangan yang bersifat diplomatik, yaitu menjalankan perhubungan dengan negara lain atau subjek hukum internasional lainnya dalam konteks hubungan luar negeri, baik dalam keadaan perang dan damai.

5. Kewenangan yang bersifat adminstratif untuk mengangkat dan memberhentikan orang dalam jabatan- jabatan kenegaraan dan jabatanjabatan administrasi negara. Hal ini disebabkan pula karena presiden juga merupakan kepala eksekutif.

6. Kewenangan dalam bidang keamanan, yakni untuk mengatur polisi dan angkatan bersenjata, menyelenggarakan perang, pertahanan negara, serta keamanan dalam negeri.

Salah satu kelemahan dalam sistem presidensil adalah sangat dimungkinkannya terjadi konflik antara parlemen dan eksekutif yang dapat menyebabkan deadlock dan kelumpuhan. Hal ini dapat saja tidak terhindarkan akibat kedudukan kedua lembaga yang masing-masing terpisah atau terbagi dan tidak bergantung satu sama lain. Oleh karena itu, ketika konflik atau ketidaksepakatan terjadi maka tidak ada institusi yang dapat menyelesaikan masalah tersebut.

29. Ibid. hlm. 15 .

30. Jimly Asshiddiqie, (2005), Format Kelembagaan Negara dan Pergeseran Kekuasaan dalam UUD 1945, Yogyakarta: FH UII Press, hlm. 75 . 
Dalam sistem politik, peran partai politik sangat penting, sebagaimana dinyatakan Miriam Budiarjo, partai politik berperan sebagai: (1) Sebagai sarana komunikasi politik yang dapat digunakan sebagai ruang untuk menggabungkan dan merumuskan berbagai kepentingan- kepentingan (interest articulation); (2) Sebagai sarana sosialisasi politik, yakni proses untuk menyampaikan budaya politik yaitu norma-norma dan nilai-nilai dari satu generasi ke generasi berikutnya; (3) Sebagai rekrutmen politik, yakni untuk memilih atau menyeleksi seorang pemimpin, baik untuk kepentingan internal maupun eksternal partai; (4) Sebagai sarana pengatur kon ik (con ict management), yakni menekan atau mengatur kon ik-kon ik yang mungkin terjadi sebagai akibat sifat heterogen suatu bangsa. ${ }^{31}$

\section{Penutup}

Pilihan pola sentralistik Negara Kesatuan, substansinya adalah kehendak untuk menyatukan wilayah dalam satu kesatuan administrasi pemerintahan, kebijakan politik ekonomi yang terpusat, dan adanya kesatuan hukum. Karakter yang menonjol dari Negara Kesatuan, terlebih pada sistem pemerintahan presidensial adalah pada pola pemerintahan yang cenderung sentralistik. Menghadapi masalah-masalah pembagian kewenangan. Adapun langkah apa yang harus dilakukan untuk dapat keluar dari masalah tersebut. Ada beberapa langkah berikut:

Pertama, berkaca pada pengalaman pelaksanaan hubungan pusat di daerah (yang bukan dengan pola otonomi khusus) lain, sebaiknya dibentuk badan ad-hoc yang dapat menjembatani penyelesaian pembagian kewenangan antara Pemerintah Pusat dengan Pemerintah Daerah (Provinsi/Kabupaten/ Kota). Pembentukan itu tidak saja menjadi salah satu bukti bahwa pemerintah serius mengelola otonomi, tetapi juga mempercepat keluar dari kecenderungan penyeragaman pola otonomi daerah di Departemen Dalam Negeri.

Kedua, pemerintah pusat mesti membuat bentuk produk hukum yang seragam dalam menyusun "norma", "standar", dan "prosedur" sehingga benarbenar tidak mengurangi kewenangan yang dimiliki oleh Pemerintahan Daerah sebagai daerah yang diberi status khusus atau istimewa. Akan lebih baik kalau produk hukum penyusunan "norma", "standar", dan "prosedur" dibuat dalam satu produk hukum.

Ketiga, membangun kominikasi yang intensif antara Pemerintahan Pusat dengan Pemerintahan Daerah (Provinsi/Kabupaten/Kota) dalam menyusun pembagian urusan antara di daerah. Komunikasi ini menjadi sangat penting agar potensi konflik pembagian urusan antara Pemerintahan Pusat dengan Pemerintahan Daerah, tidak menjadi disharmonisasi dalam pelaksanaan penyelenggaraan pemerintahan, dimana mengakibatkan pelemahan terhadap sistem presidensial

Struktur kabinet pemerintahan mendatang perlu dipastikan mampu mendorong adanya koordinasi dan sinkronisasi yang lebih baik dalam menyelesaikan berbagai persoalan, baik antar-kementerian, lembaga, maupun hubungan pusat dan daerah. Selama ini ada banyak sumbatan antara kebijakan pemerintah pusat dan program-program pembangunan pemerintah daerah. Sumbatan yang mengakibatkan bottle neck itu terutama disebabkan 2 (dua) hal, yaitu aturan dan regulasi pusat yang saling tak sinkron dan tumpang tindih. Instansi pusat juga masih mementingkan ego masing-masing. Kabinet sebaiknya memenuhi empat sehat lima sempurna. Empat sehat, yaitu terdiri atas para menteri yang ahli, dipilih dari orang-orang profesional, tak terbelenggu kepentingan partai, dan memenuhi keterwakilan wilayah atau berasal dari berbagai daerah. Lima sempurna, yaitu memiliki visi dan misi yang satu dengan dewan menteri terutama dengan presiden.

Hubungan antara pemerintah daerah dan pemerintah pusat harus harmonis agar terwujud koordinasi yang baik, sinkronisasi kebijakan, serta kerja sama yang solid. Dengan demikian, pembangunan yang dirancang pemerintah pusat, provinsi, dan kabupaten/kota dapat selaras. Pokok permasalahan tersebut menghendaki satu perubahan mendasar hubungan antara pusat dan daerah. Dengan kata lain, perlu dipikirkan konstruksi baru hubungan antara pusat dan daerah. Konstruk hubungan tersebut paling tidak memuat pemikiran ulang mengenai tingkatan pemerintahan, status dan

31. Miriam Budiarjo, op. cit., hlm. 405. 
kedudukannya; pembagian wewenang (atau urusan) antar berbagai tingkatan pemerintahan; perimbangan keuangan antar tingkatan pemerintahan; partisipasi daerah dalam pembuatan keputusan di tingkat nasional; dan intervensi pusat terhadap daerah.

\section{Daftar Pustaka}

Asshiddiqie, Jimly. (2005), Implikasi Perubahan UUD 1945 Terhadap Pembangunan Hukum Nasional, Mahkamah Konsitusi RI, Jakarta.

(2005), Format Kelembagaan Negara dan Pergeseran Kekuasaan dalam UUD 1945, FH UII Press, Yogyakarta.

(2007), Pokok-pokok Hukum Tata Negara Indonesia Pasca Reformasi, Bhuana Ilmu Populer, Jakarta.

Budardjo, Miriam. (2009), Dasar-Dasar Ilmu Politik, Gramedia Pustaka Utama, Jakarta.

Haris, Syamsuddin (ed), (2007), Desentralisasi dan Otonomi Daerah (Desentralisasi, Demokratisasi dan Akuntabilitas Pemerintahan Daerah), LIPI Press, Jakarta.

Lijphart, Arend, (2002), Parliamentary versus Presidential Government, Oxford University Press, New York.

Manan, Bagir. (1994), Hubungan Antara Pusat dan Daerah Menurut UUD 1945, Pustaka Sinar Harapan, Jakarta.

(1999), Lembaga Kepresidenan, Gama Media, Ypgyakarta.

Ranadureksa, Hendarmin, (2007), Arsitektur Konstitusi Demokratik, Fokusmedia, Bandung.

Syafruddin, Ateng, (1993), Pengaturan Koordinasi Pemerintahan Di Daerah, Citra Aditya Bakti, Bandung.

Eko Parsojo, (2006), Konstruksi Ulang Hubungan Pemerintah Pusat dan Pemerintah Daerah di Indonesia: Antara Sentripetalisme dan Sentrifugalisme, Pidato Pengukuhan sebagai Guru Besar Tetap FISIP UI, Depok, 2006,
Saldi Isra, Pembagian Kewenangan Pusat-Daerah dalam Perspektif Undang-Undang Pemerintahan Aceh, Makalah, diselenggarakan oleh Forum LSM Aceh bekerja sama dengan Forbes BRA, di Banda Aceh, 22 Novemver 2006.

Yappika, (2006), disadur dari "Laporan akhir sosialisasi Pemehaman\& Sosialisasi Penyusunan RUU Tata Hubungan Kewenangan Pemerintah Pusat \& Daerah", Kementerian Negara PAN berkerjaama dengan Pusat Kajian Administrasi Daerah dan Kota, FISIP UI, Depok, 2006.

Saldi Isra, Problematik Koalisi Dalam Sistem Presidensial, Makalah, 2010

Andryan, Pencabutan Perda, Harian Waspada, Senin 27 Juni 2016

Saldi Isra, Gagasan Bernegara Yamin, Majalah Tempo, 2 September 2014

https: / / www.saldiisra.web.id/index.php/bukujurnal/jurnal/19-jurnalnasional/336pembagian-kewenangan-pusat-daerah-dalamundang-undang-nomor-11-tahun-2006tentang-pemerintahan-aceh.html. Di akses pada tanggal 25 Juli 2019

Republik Indonesia, Undang-Undang Dasar Tahun 1945

Republik Indonesia, Undang-Undang Nomor 23 Tahun 2014 tentang Pemerintah Daerah Lembaran Negara Republik Indonesia Tahun 2014 Nomor 244 